\title{
Effects of parent material, stand type and oak species on defoliation of coppice-originated oak (Quercus spp.) forests in Northern Turkish Thrace
}

\author{
Efectos del material parental del suelo y de la especie de encina en la defoliación \\ de las copas en bosques nativos de encina (Quercus spp.) en el norte de Tracia, Turquía
}

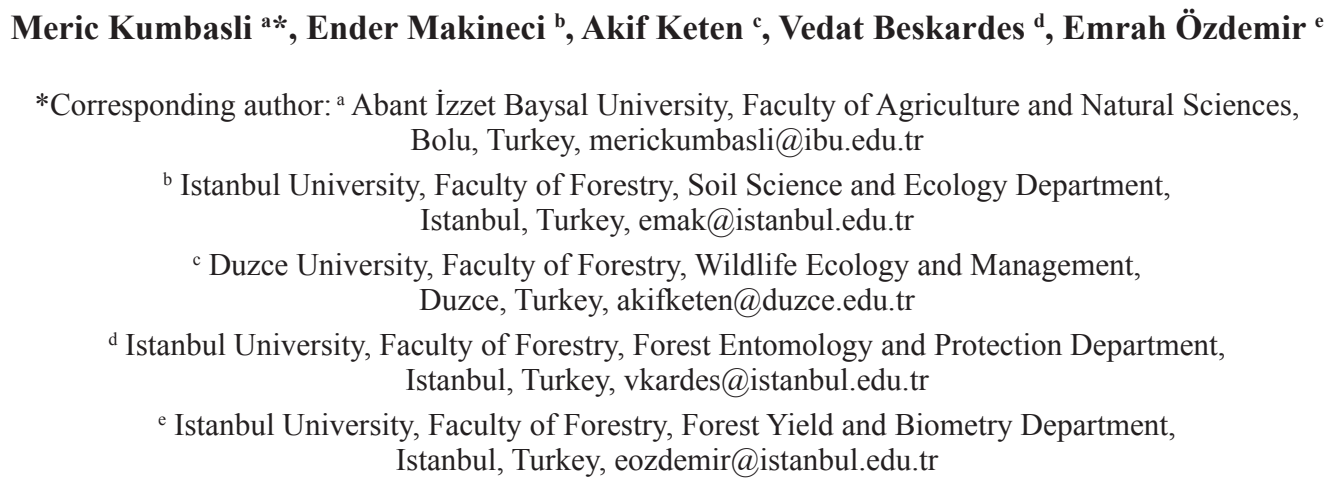

\section{SUMMARY}

Cases of significant defoliation in oak (Quercus spp.) forests have been reported in Turkey and throughout the world. Oak trees are important in Turkish forests and forestry and cover vast pieces of land in Thrace. In this study, in a quest to determine the general health condition of pure oak forests in Northern Turkish Thrace, the defoliation rate of tree crowns was evaluated for 8,769 trees in 336 sample plots corresponding to different geological parent materials, regions, oak species and stand types. The defoliation rates were designated and assessed based on the criteria of the European Union Forest Health Monitoring Program (UNECE-ICP Forests). The defoliation rate was, to a significant extent, affected by stand type, the geological parent material, and oak species. In general, $47 \%$ of trees exhibited defoliation. The highest ratio of defoliation was found in Kirklareli Region, where water deficit was the highest, and the parent material was schist-calcschist. Medium diameter forests (MDF, mean dbh: 8-20 cm, ratio of defoliated trees $=65 \%$ ) among stand types, and sessile oaks (ratio of defoliated trees $=53 \%$ ) among oak species, had the highest defoliation rates. Achieved results demonstrated that the defoliation classes in observed oak stands have a significant relation with variables concerning stand types, oak species and geological parent materials.

Key words: coppice, crown transparency, forest health, ICP forest, oak decline.

\section{RESUMEN}

Se han notificado casos de defoliación significativa en bosques de encina (Quercus spp.) en Turquía y en el mundo. Las encinas son importantes en los bosques turcos y cubren grandes extensiones en Tracia. En este estudio, para determinar el estado de salud general de los bosques de encina puros, en Tracia turca septentrional, se evaluó la tasa de defoliación de las copas de los árboles en 336 parcelas correspondientes a diferentes materiales geológicos formadores del suelo, regions geográficas, especies de encina y tipos de rodales. Las tasas de defoliación fueron evaluadas a base de los criterios del Programa de Vigilancia de la Salud Forestal de la Unión Europea (UNECE-ICP Forests). La tasa de defoliación fue, en gran medida, afectada por el tipo de rodal, el material de origen geológico y las especies de encina. En general, el 47 \% de los árboles presentaba defoliación. La mayor proporción de defoliación se encontró en la región de Kirklareli, donde el déficit hídrico fue el más alto y el material parental fue calcáreo; en los bosques de diámetro medio (dap promedio: 8-20 cm, proporción de árboles defoliados $=65 \%$ ) entre los tipos de rodales, y en las encinas sésiles (proporción de árboles defoliados $=53 \%$ ) entre las especies de encina. Los resultados obtenidos demostraron que las clases de defoliación en los rodales de encina tienen relación significativa con variables relativas a tipos de rodales, especies de encinas y materiales parentales geológicos.

Palabras clave: copas, transparencia de copa, salud forestal, bosque ICP, decadencia de encinas.

\section{INTRODUCTION}

Forests have been facing serious threats during the $21^{\text {st }}$ century despite some encouraging trends (Millar and Ste- phenson 2015), furthermore, novel patterns proposed that forest decline is changing (Haavik et al. 2015). The decline of forest ecosystems is the subject of many scientific studies. Poorly understood biotic and abiotic factors are invol- 
ved in forest decline, causing reduction in tree vigor and growth, degradation of roots and foliage, and ultimately accelerating tree mortality. The most important criterion for the identification and quantification of tree decline is the determination of the defoliation rate of tree crown (Sonesson 1999). These health problems are important in oak forests included in decline studies in the last decades (Fan et al. 2012). Complex biotic and abiotic interactions are believed to be responsible for oak decline (Sallé et al. 2014, Bendixsen et al. 2015, Haavik et al. 2015). Symptoms of significant deterioration in the health of oak trees are starting to be observed around the world and, lately, in Turkey. The death of oaks begins with a process of tree crown deterioration year after year, from the distal branches of the crown towards the trunk. Other symptoms of oak decline are: changes in leaf color, early leaf fall, and the development of epicormic shoots (Makineci et al. 2011).

Oaks (Quercus spp.) have wide distribution through Europe, Asia and North America, representing half of all forest cover (Bendixsen et al. 2015, Haavik et al. 2015, Tulik and Bijak 2016) and are ecologically, economically and culturally relevant (Sallé et al. 2014). Oaks are also economically important for the Turkish forestry due to the variety of oak species and the extent of the area they occupy. In Turkey, oaks cover $22.4 \%$ of the total forest area, i.e. the second largest forest area after pines (Makineci et al. 2011).

The Northern Thrace Region of Turkey, where the present study was conducted, is an important area in which oaks are widely prevalent. According to the latest surveys, forest lands cover an area of 656,004 ha, which is $27.66 \%$ of the entire land area, and oak forests make up $71.65 \%$ of the forest lands in Thrace (Makineci et al. 2011). Coppice forests are man-made secondary forests (Nakajima and Ishida 2014) that were cut every 20 years, and usually regenerated themselves via sprouting. Almost all coppice forest management was abandoned mainly in 2006 in Turkey, with the idea of "converting coppices into high forests", following the decision taken by the Ministry of Forestry and Water Affairs (MFWA) (Makineci et al. 2011). However, coppicing might have the advantage of a fully functional root system, which facilitates rapid resprouting, whereas the rotation of tree stands would likely lead to the degradation of root systems (Makineci et al. 2015).

The main objectives of the study are to determine the defoliation rates of oak trees, and to investigate relationships between defoliation rates-classes and other investigated parameters including different stand types, different oak species and different geological parent materials in various regions in the coppice-originated oak forests in the Northern Thrace Region of Turkey. Our hypotheses are that: (i) soils derived from different parent materials have different significant properties effecting oak health. In addition to soil, sampled stands on different geological parent materials at different regions have various climatic characteristics regarding precipitation, temperature and water deficit. Less precipitation and more water deficit will possibly enhance defoliation; (ii) stands at different development stages have different degrees of resistance to defoliation, possibly young stands have the highest resistance and tolerance; (iii) different oak species have possibly different species-specific characteristics, therefore, some oak species will be affected by oak decline in more or less extension.

\section{METHODS}

Site description. Sample plots were selected among pure coppice-originated oak stands having different oak species composition on different geological parent materials in different regions and stand types in Northern Thrace-Turkey (figure 1). The stands are characterized as pure oak stands, with varying dominance of three major species: Sessile oak (Quercus petraea (Mattuschka) Liebl.), Hungarian oak (Quercus frainetto Ten.), and Turkey oak (Quercus cerris L.) (Makineci et al. 2015). Climate data (precipitation, temperature and water deficit) and geological parent materials in different regions are presented in table 1.

Sampling and sampling design. Field studies were conducted in the years 2008, 2009 and 2010, during the months of July and August, which are the most convenient months for tree crown observation as leaf maturing is generally complete. To be able to take samples of the soils that have developed from two different geological parent materials in each of the regions, the dominant parent materials were identified from geological maps (table 1).

Stand type was also included as a criterion for the separation of sample plots. The stand types were identified through the forest management plans using the classification categories of MFWA and field studies (Makineci et al. 2015). Stand types were classified as small-diameter forests $(\mathrm{SDF}$, mean tree diameter at breast height (dbh): 0-8 cm), medium-diameter forests (MDF, dbh: 8-20 cm), large-diameter forests (LDF, dbh: 20-36 cm) and degraded forests (DF, canopy closure $<10 \%$ ). In the areas separated according to these criteria, six replicated $20 \times 20 \mathrm{~m}$ sample plots were selected. In summary, determination of defoliation rates was conducted on seven different regions, two different dominant geological parent materials and four stand types with six replicated sample plots, totaling 336 $(7 \times 2 \times 4 \times 6=336)$ sample plots in which 8,769 trees were observed. The mean stand ages were determined as DF $=$ $19, \mathrm{SDF}=14, \mathrm{MDF}=65$, and $\mathrm{LDF}=83$ (Makineci et al . 2011, 2015).

Determination of defoliation rates. The defoliation rates of the trees on each sample plot were conducted in line with the tree crown condition observation and supervision method of the European Union (UNECE) ICP Forests (UNECE 2004). The defoliation ratio of each tree inside the sample plots was assessed. 
The observation of tree crowns was conducted under clear and no cloudy day conditions by at least two people (obtaining a mean value after observation) with the assistance of binoculars. Crown defoliation rate was determi- ned with an evaluation of the top $2 / 3$ of the crown. This observation included the loss of leaves, transparency of the tree crown, and lost and dead branches. Estimations of defoliation rates were made by contrast with a fully-foliated

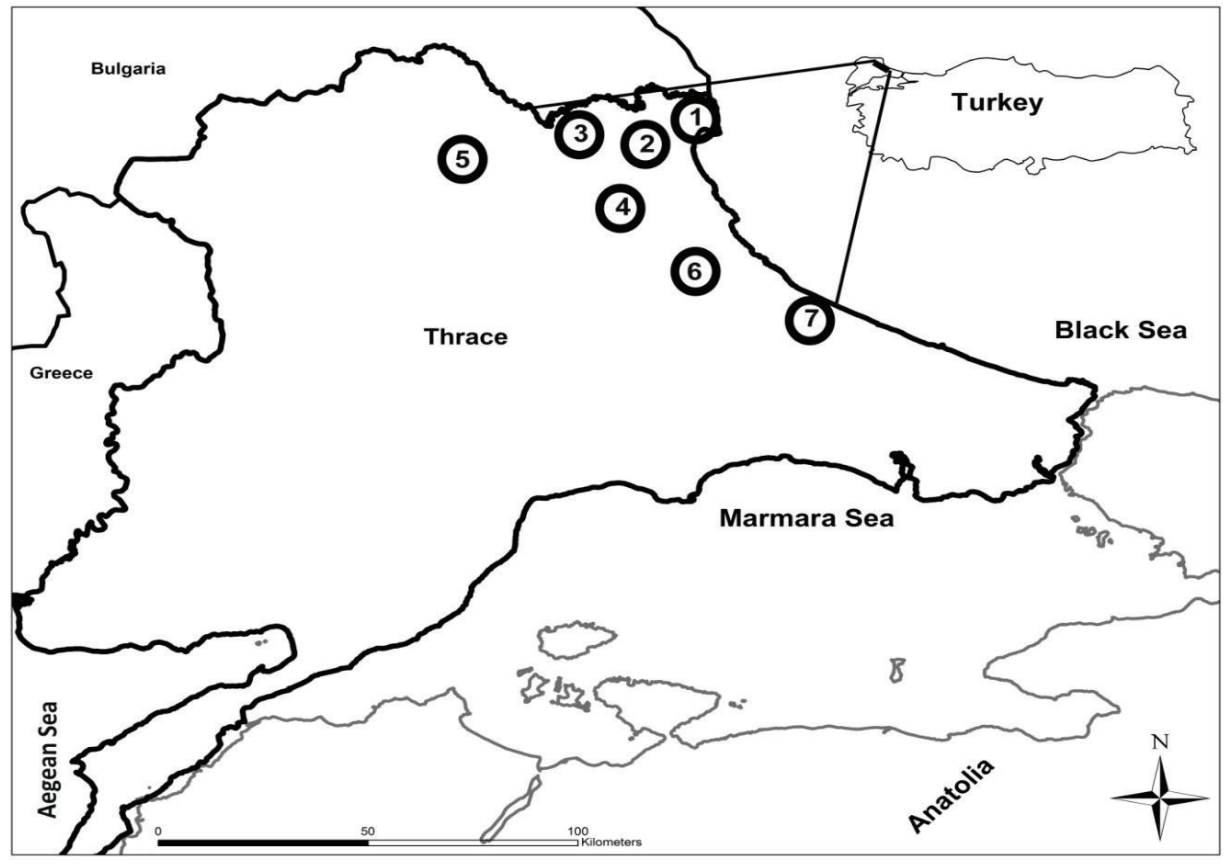

Figure 1. Sampling regions on coppice-originated oak forests, 1: Demirkoy1 (D1), 2: Demirkoy2 (D2), 3: Demirkoy3 (D3), 4: Demirkoy4 (D4), 5: Kirklareli, 6: Vize, 7: Catalca.

Regiones de muestreo en bosques nativos de encina originados. 1: Demirkoy1 (D1), 2: Demirkoy2 (D2), 3: Demirkoy3 (D3), 4: Demirkoy4 (D4), 5: Kurklareli, 6: Vize, 7: Catalca.

Table 1. Climate data and geological parent materials in different regions of research area (Makineci et al. 2015).

Datos climáticos y materiales parentales geológicos en diferentes regiones del área de investigación (Makineci et al. 2015).

\begin{tabular}{|c|c|c|c|c|c|}
\hline Regions & Altitude (m) & $\begin{array}{l}\text { Mean annual } \\
\text { precipitation } \\
(\mathrm{mm})\end{array}$ & $\begin{array}{c}\text { Average annual } \\
\text { temperature } \\
\left({ }^{\circ} \mathrm{C}\right)\end{array}$ & $\begin{array}{c}\text { Annual water } \\
\text { deficit } \\
(\mathrm{mm})\end{array}$ & $\begin{array}{c}\text { Geological } \\
\text { Parent materials }\end{array}$ \\
\hline $\begin{array}{l}\text { Demirkoy1 } \\
\text { (D1) }\end{array}$ & 682 & 1.053 & 11 & 84 & $\begin{array}{l}\text { Schist-calcschist } \\
\text { Metagranitoid }\end{array}$ \\
\hline $\begin{array}{l}\text { Demirkoy2 } \\
\text { (D2) }\end{array}$ & 381 & 837 & 12 & 158 & $\begin{array}{c}\text { Granitoid } \\
\text { Metagranitoid }\end{array}$ \\
\hline $\begin{array}{l}\text { Demirkoy3 } \\
\text { (D3) }\end{array}$ & 125 & 866 & 13 & 181 & $\begin{array}{l}\text { Pebble-sandstone-mudstone } \\
\text { Volcanic sedimentary- shelf }\end{array}$ \\
\hline $\begin{array}{l}\text { Demirkoy4 } \\
\text { (D4) }\end{array}$ & 391 & 838 & 12 & 156 & $\begin{array}{c}\text { Granitoid } \\
\text { Schist-calcschist }\end{array}$ \\
\hline Kirklareli & 493 & 550 & 14 & 274 & $\begin{array}{c}\text { Marble } \\
\text { Schist-calcschist }\end{array}$ \\
\hline Vize & 322 & 720 & 12 & 244 & $\begin{array}{l}\text { Limestone } \\
\text { Augen gneiss- metagranitoid }\end{array}$ \\
\hline Çatalca & 290 & 844 & 14 & 212 & $\begin{array}{l}\text { Quartzite-quartzschist } \\
\text { Augen gneiss- metagranitoid }\end{array}$ \\
\hline
\end{tabular}


tree (reference tree). The tree defoliation classes according to defoliation rates were set apart as in ICP standard studies (UNECE 2004; table 2).

Statistical evaluation. To determine whether there was dependency or not between defoliation classes and the independent variables (stand types, oak tree species and geological parent materials) chi-square tests were applied at a 0.05 significance level. The Pearson chi-square value was used in the test because no more than $20 \%$ of the cells have expected values (frequencies) inferior to 5 in crosstabulations.

\section{RESULTS}

The defoliation classes in oak stands display a statistically significant dependence on variables concerning stand types, oak species and geological parent materials according to chi-square tests $(P<0.001)$. In the oak stands of Northern Thrace, defoliation rates are affected to a high extent by the type of stand, the composition of oak species and the geological parent material (table 3).

In a general evaluation, the ratio of healthy trees, i.e. those in which symptoms of defoliation were not observed, was $52.9 \%$. Approximately half of the 8,769 trees that were examined in the research area had different degrees of defoliation. When the distribution of the numbers of defoliated trees within each defoliation class was analyzed, the moderate defoliation class (25-60 \%) included the highest percentage of trees $(19.5 \%)$, whereas the class of $<10$ $\%$ defoliation rate included the lowest percentage (1.4\%). The total percentage of "severe defoliation" and "dead or dry trees" classes constituted $26 \%$ of all defoliated trees, and approximately $12 \%$ of all observed trees (table 4 ).

The ratios of defoliated trees that have been identified on different geological parent materials vary between $9.4 \%$ (D3 region, pebble-sandstone-mudstone parent material) and $89.3 \%$ (Kurklareli Region, schist-calcschist parent material). Among regions, D3 had the lowest and Kirklareli the highest defoliation rates (table 5).

Table 2. Defoliation classes of trees (UNECE 2004).

Clases de defoliación de árboles (UNECE 2004).

\begin{tabular}{clc}
\hline Defoliation classes & Description & Defoliation rates (\%) \\
\hline 0 & No defoliation & $0-10$ \\
1 & Slight defoliation & $11-25$ \\
2 & Moderate defoliation & $26-60$ \\
3 & Severe defoliation & $61-99$ \\
4 & Dead/dry trees & 100 \\
\hline
\end{tabular}

The number of defoliated trees in different stand types varied between 262 (DF) and 1,946 (MDF). The evaluation of the number of trees in different defoliation classes over different stand types shows that $65.5 \%$ of trees in both MDF and LDF stand types exhibit some degree of defoliation. Among stand types, the lowest ratio (total number of defoliated trees to total number of trees) corresponded to the SDF stand type ( $23.0 \%$; table 6$)$.

Among the oak species, the numbers of defoliated trees varied between 331 (Quercus cerris) and 3158 (Quercus petraea; table 7). The most defoliated species was sessile oak (Quercus petraea); over half of sessile oak trees (54\%) were defoliated and almost $10 \%$ of them were dead. The percentage of defoliated trees was intermediate in Quercus frainetto (36\%) and the lowest in Quercus cerris (28\%; table 7).

\section{DISCUSSION}

Oak deaths are striking in regions of North America and Europe, parallel to the findings in the current research. The important effects of abiotic factors on these deaths are emphasized by some research such as: on red oak species in Arkansas and Misouri-USA (Fan et al. 2012), on Quercus rubra L. in Arkansas-USA (Haavik et al. 2011), on mixed oak forests in Central Europe (Kuster et al. 2013) and on Quercus petraea and Quercus robur L. in Northwestern Germany (Thomas et al. 2002).

The highest degree of defoliation found here for oak trees corresponded to the Kirklareli Region. The Kirklareli Region has the highest annual water deficit among the regions included in this research $(274 \mathrm{~mm})$. In addition, soils that derived from schist-calcschist parent materials, which are prevalent at the Kirklareli Region, are clay texture, poor in water, stagnancy of water (pseudogley soil), and hence, low water and gas permeability. In schist-calcschist

Table 3. Chi-Square test statistics between defoliation classes and variables.

Estadísticas de Chi-Cuadrado entre las clases de defoliación y las variables.

\begin{tabular}{lccc}
\hline \multirow{2}{*}{ Variables } & \multicolumn{3}{c}{ Defoliation classes } \\
\cline { 2 - 4 } & \multicolumn{1}{c}{$\begin{array}{c}\text { df } \\
\text { (degrees of freedom)* }\end{array}$} & $\begin{array}{c}\text { Pearson } \\
\text { Chi-Square }\end{array}$ & $P$ \\
\hline Stand types & 12 & 266.748 & 0.000 \\
Oak species & 8 & 116.586 & 0.000 \\
$\begin{array}{l}\text { Geological parent } \\
\text { materials }\end{array}$ & 52 & $1,163.545$ & 0.000 \\
\hline
\end{tabular}

*Degree of freedom $(\mathrm{df})=($ number of defoliation classes -1$) \mathrm{x}$ the number of investigated variables. 
Table 4. Distribution of trees in different defoliation classes.

Distribución de árboles en diferentes clases de defoliación.

\begin{tabular}{lcccc}
\hline \multicolumn{1}{c}{ Type of tree } & Defoliation classes & Defoliation rates (\%) & Number of trees & (\%) \\
\hline Healthy tree & & No defoliation & 4,642 & 52.9 \\
\hline \multirow{3}{*}{ Defoliated tree } & 0 & $0-10$ & 112 & 1.4 \\
& 1 & $11-25$ & 1,221 & 13.9 \\
& 2 & $26-60$ & 1,714 & 19.5 \\
& 3 & $61-99$ & 749 & 8.5 \\
& 4 & 100 & 331 & 3.8 \\
\hline
\end{tabular}

Table 5. Distribution of defoliated trees corresponding to different parent materials.

Distribución de árboles defoliados correspondientes a diferentes materiales de origen.

\begin{tabular}{|c|c|c|c|c|c|c|c|c|c|}
\hline \multirow[b]{3}{*}{ Region } & \multirow[b]{3}{*}{ Parent material } & \multicolumn{6}{|c|}{ Number of defoliated trees } & \multirow{3}{*}{$\begin{array}{l}\text { Number } \\
\text { of healthy } \\
\text { trees }\end{array}$} & \multirow{3}{*}{$\begin{array}{c}\text { Total } \\
\text { number of } \\
\text { trees }\end{array}$} \\
\hline & & \multicolumn{6}{|c|}{ Defoliation classes and rates $(\%)$} & & \\
\hline & & $\begin{array}{c}0 \\
(0-10 \%)\end{array}$ & $\begin{array}{c}1 \\
(11-25 \%)\end{array}$ & $\begin{array}{c}2 \\
(26-60 \%)\end{array}$ & $\begin{array}{c}3 \\
(61-99 \%)\end{array}$ & $\begin{array}{c}4 \\
(100 \%)\end{array}$ & $\begin{array}{l}\text { Total number of } \\
\text { defoliated trees } \\
\text { and ratio to total } \\
\text { number of trees }\end{array}$ & & \\
\hline \multirow{2}{*}{$\begin{array}{l}\text { Demirkoy1 } \\
\text { (D1) }\end{array}$} & schist-calcschist & 6 & 103 & 131 & 39 & 47 & $326(70.9 \%)$ & 134 & 460 \\
\hline & metagranitoid & 21 & 156 & 153 & 49 & 42 & $421(72.3 \%)$ & 161 & 582 \\
\hline \multirow{2}{*}{$\begin{array}{l}\text { Demirkoy2 } \\
\text { (D2) }\end{array}$} & granitoid & 17 & 2 & 16 & 33 & 34 & $102(13.7 \%)$ & 641 & 743 \\
\hline & metagranitoid & 13 & 5 & 29 & 33 & 27 & $107(15.5 \%)$ & 581 & 688 \\
\hline \multirow{2}{*}{$\begin{array}{l}\text { Demirkoy3 } \\
\text { (D3) }\end{array}$} & $\begin{array}{l}\text { pebble-sandstone- } \\
\text { mudstone }\end{array}$ & 10 & 0 & 13 & 21 & 13 & $57(9.4 \%)$ & 551 & 608 \\
\hline & $\begin{array}{c}\text { volcanic } \\
\text { sedimentary- shelf }\end{array}$ & 3 & 5 & 33 & 34 & 25 & $100(12.4 \%)$ & 704 & 804 \\
\hline \multirow{2}{*}{$\begin{array}{l}\text { Demirkoy4 } \\
\text { (D4) }\end{array}$} & granitoid & 14 & 42 & 51 & 69 & 15 & $191(28.8 \%)$ & 472 & 663 \\
\hline & schist-calcschist & 3 & 33 & 47 & 89 & 12 & $184(38.9 \%)$ & 288 & 472 \\
\hline \multirow{2}{*}{ Kirklareli } & schist-calcschist & 5 & 107 & 257 & 28 & 12 & $409(89.3 \%)$ & 49 & 458 \\
\hline & marble & 18 & 117 & 188 & 23 & 3 & $349(72.1 \%)$ & 135 & 484 \\
\hline \multirow[b]{2}{*}{ Vize } & limestone & 0 & 80 & 246 & 82 & 27 & $435(83.2 \%)$ & 88 & 523 \\
\hline & $\begin{array}{l}\text { augen gneiss- } \\
\text { metagranitoid }\end{array}$ & 1 & 102 & 225 & 111 & 32 & $471(56.3 \%)$ & 366 & 837 \\
\hline \multirow{2}{*}{ Çatalca } & $\begin{array}{c}\text { quartzite- } \\
\text { quartzschist }\end{array}$ & 0 & 239 & 140 & 73 & 34 & $486(72.6 \%)$ & 183 & 669 \\
\hline & $\begin{array}{l}\text { augen gneiss- } \\
\text { metagranitoid }\end{array}$ & 1 & 230 & 185 & 65 & 8 & $489(62.8 \%)$ & 289 & 778 \\
\hline Total & 11 & & 1,221 & 1,714 & 749 & 331 & $4,127(47.1 \%)$ & 4,642 & 8,769 \\
\hline
\end{tabular}


Table 6. Distribution of defoliated trees in different stand types.

Distribución de árboles defoliados en diferentes tipos de rodales.

\begin{tabular}{|c|c|c|c|c|c|c|c|c|}
\hline \multirow{3}{*}{$\begin{array}{l}\text { Stand } \\
\text { types }\end{array}$} & \multicolumn{6}{|c|}{ Number of defoliated trees } & \multirow{3}{*}{$\begin{array}{l}\text { Number of } \\
\text { healthy trees }\end{array}$} & \multirow{3}{*}{$\begin{array}{c}\text { Total number } \\
\text { of trees }\end{array}$} \\
\hline & \multicolumn{6}{|c|}{ Defoliation classes and rates $(\%)$} & & \\
\hline & $\begin{array}{c}0 \\
(0-10 \%)\end{array}$ & $\begin{array}{c}1 \\
(11-25 \%)\end{array}$ & $\begin{array}{c}2 \\
(26-60 \%)\end{array}$ & $\begin{array}{c}3 \\
(61-99 \%)\end{array}$ & $\begin{array}{c}4 \\
(100 \%)\end{array}$ & $\begin{array}{c}\text { Total number of } \\
\text { defoliated trees and ratio } \\
\text { to total number of trees }\end{array}$ & & \\
\hline DF & 19 & 90 & 78 & 62 & 13 & $262(36.6 \%)$ & 454 & 716 \\
\hline SDF & 46 & 260 & 224 & 131 & 101 & $762(23.0 \%)$ & 2,555 & 3,317 \\
\hline MDF & 26 & 451 & 879 & 411 & 179 & $1,946(65.5 \%)$ & 1,024 & 2,970 \\
\hline LDF & 21 & 420 & 533 & 145 & 38 & $1,157(65.5 \%)$ & 609 & 1,766 \\
\hline Total & 112 & 1,221 & 1,714 & 749 & 331 & $4,127(47.1 \%)$ & 4,642 & 8,769 \\
\hline
\end{tabular}

(SDF: small-diameter forests, mean $\mathrm{dbh}=0-8 \mathrm{~cm}$ ), (MDF: medium-diameter forests, dbh: 8-20 cm), (LDF: large-diameter forests, dbh=20-36 cm) and (DF: degraded forests, canopy closure $<10 \%$ ).

Table 7. Distribution of defoliated trees in different oak species.

Distribución de árboles defoliados en diferentes especies de encina.

\begin{tabular}{|c|c|c|c|c|c|c|c|c|}
\hline \multirow{3}{*}{$\begin{array}{c}\text { Oak } \\
\text { species }\end{array}$} & \multirow{3}{*}{$\begin{array}{l}\text { Number of } \\
\text { healthy trees }\end{array}$} & \multicolumn{6}{|c|}{ Number of defoliated trees } & \multirow{3}{*}{$\begin{array}{c}\text { Total number } \\
\text { of trees }\end{array}$} \\
\hline & & \multicolumn{6}{|c|}{ Defoliation classes and rates $(\%)$} & \\
\hline & & $\begin{array}{c}0 \\
(0-10 \%)\end{array}$ & $\begin{array}{c}1 \\
(11-25 \%)\end{array}$ & $\begin{array}{c}2 \\
(26-60 \%)\end{array}$ & $\begin{array}{c}3 \\
(61-99 \%)\end{array}$ & $\begin{array}{c}4 \\
(100 \%)\end{array}$ & $\begin{array}{l}\text { Total number of } \\
\text { defoliated trees and ratio } \\
\text { to total number of trees }\end{array}$ & \\
\hline $\begin{array}{l}\text { Quercus } \\
\text { frainetto }\end{array}$ & 1,110 & 30 & 108 & 336 & 130 & 34 & $638(36.5 \%)$ & 1,748 \\
\hline $\begin{array}{l}\text { Quercus } \\
\text { cerris }\end{array}$ & 839 & 10 & 110 & 166 & 31 & 14 & $331(28.3 \%)$ & 1,170 \\
\hline $\begin{array}{l}\text { Quercus } \\
\text { petraea }\end{array}$ & 2,693 & 72 & 1,003 & 1,212 & 588 & 283 & $3,158(54.0 \%)$ & 5,851 \\
\hline Total & 4,642 & 112 & 1,221 & 1,714 & 749 & 331 & $4,127(47.1 \%)$ & 8,769 \\
\hline
\end{tabular}

that emerged through the metamorphosis of these parent materials as a result of high temperature and pressure, the formation of soil is slow and soils are generally shallow (Kantarci 2000). The combination of these negative factors can contribute to the high level of defoliation in this region and parent material. On the other hand, the oaks at the region of $\mathrm{D} 3$, emerging on parent materials of pebblesandstone-mudstone and volcanic sedimentary-shelf, exhibited the lowest levels of defoliation. In this region, the intermediate level of water deficit may have been compensated by a positive effect of the parent materials that have formed the soil. There are many studies that draw attention to the different properties of parent materials and soils regarding oak deaths; some examples are: fragipan soils (Rampelberg et al. 1997), decrease in the gas permeability of the soil (Gaertig et al. 2002), high stagnant water (pseudogley soils) and soil compaction (Kantarci et al. 2005).
The low extent of defoliation registered for younger stands (SDF) can be explained by the fact that these stands are supported by an extensive root system. However, the fast increase in the biomass of MDF stands may cause the defoliation because the available old root systems may not support this fast growing biomass. In LDF stands, defoliation reached a lower level compared with those at MDF. This could be explained through the effect of selective forces: only those individuals with higher endurance would have reached LDF. Sonesson (1999), in contrast, remarked that oak deaths in Sweden increase with stand age, whereas Drobyshev et al. (2007) reached the conclusion that there is no direct relationship between defoliation rate and stand stage in Swedish forests. Haavik et al. (2011) compared the growth of healthy and declining oak trees by means of dendrochronological research, and concluded that healthy oak trees in all age classes grew at slower rates than do de- 
clining and/or recently dead trees. This interaction between growth rate and health was a common theme in other cases of oak decline. These authors discussed the roles of three possible factors on this interaction: carbon allocation, tree age, and microsite conditions (Haavik et al. 2011).

Studies investigating oak deaths have been conducted in other regions. Brasier (2003) draws attention to deaths in Q. ilex L. and Q. suber L. in Spain and Portugal and in Q. robur in Central and Middle Europe. Camy et al. (2002) state that $Q$. robur is the oak species that is primarily affected by deaths in European forests, and argues that the reason for this is that $Q$. robur demands soils rich in nutrients; although, it is planted beyond its optimum distribution area. Fan et al. (2012) described that, among oaks, the red oak group species (Quercus Section Lobatae), mainly including scarlet oak ( $Q$. coccinea Muenchh.), black oak (Q. velutina $\mathrm{Lam}$.), northern red oak ( $Q$. rubra), blackjack oak (Q. marilandica Muenchh.) and southern red oak (Q. falcata Michx.), have suffered moderate to severe "oak decline syndrome" in the upland oak forests. Similarly, Shiffley et al. (2006) carried out with the purpose of determining risk factors in oak deaths, and they have indicated that red oaks die quicker and are more prone to diseases than white oaks; red oaks are six times more frequently affected by diseases and death than white oaks. Contrary to the findings of Shiffley et al. (2006), in the current research area, the Turkey oak, included among red oaks, is the species that has the lowest defoliation rate. In the same research area, Kumbasli et al. (2011) observed that Quercus cerris was strong to hemiparasitic agents (mistletoe) due to special structure (thick bark) and trunk secretes (a brown liquid).

The forests of the Northern Turkish Thrace have undergone excessive damage in vast areas; about $88.5 \%$ of the broad-leaved high forests that have turned into degraded coppice and old trees are rarely encountered. The fact that oak trees are regarded as more valuable for various purposes has meant even more important damage on oak stands (Eraslan and Evcimen 1967). These forests have been transformed into coppice as a result of years of irregular and continuous cutting, and their integrity has been shattered through excessive grazing and nonprocedural exploitation (Makineci et al. 2011).

\section{CONCLUSIONS}

In conclusion, the results obtained on defoliation rates demonstrated that the oak forests in the research area have a significant health problem: defoliation is observed approximately in half of the trees. The observations demonstrated that our hypotheses were not failed; the importance of different parent materials on different sites are most closely linked to defoliation. Highest water deficiency of Kirklareli site shows clear drought effects and main soil properties of schist-calcschist parent material can give more explanatory results on defoliation of oak. Also, young oak stands can cope with oak decline and Quercus cerris has more resistance proving species-specific tolerance. Further studies accounting for biotic and abiotic factors additional to those investigated here may provide more information on the health condition of oak forests in Northern Turkish Thrace.

\section{ACKNOWLEDGEMENTS}

The authors wish to thank for comments and suggestions from anonymous reviewers and the editor whose remarks and indications significantly improved the original manuscript. This work was supported by TUBITAK (The Scientific and Technological Research Council of Turkey), Project number: TOVAG-107O750. We thank to Istanbul Regional Forestry Directorate for their assistance and support in field work.

\section{REFERENCES}

Bendixsen DP, SW Hallgren, AE Frazier. 2015. Stress factors associated with forest decline in xeric oak forests of southcentral United States. Forest Ecology and Management 347: 40-48.

Brasier C. 2003. Sudden oak death: Phytophthora ramorum exhibits transatlantic differences. Mycological Research 107(3): 258-259.

Camy C, C Delatour, B Marçais. 2002. Relationships between soil factors, Quercus robur health, Collybia fusipes root infection and Phytophthora presence. Annals of Forest Science 60: 419-426.

Drobyshev I, S Anderson, K Sonesson. 2007. Crown condition dynamics of oak in southern Sweden 1988-1999. Environmental Monitoring and Assessment 134: 199-210. DOI 10.1007/s10661-007-9610-9

Eraslan İ, BS Evcimen. 1967. Trakya'da meşe ormanlarının hacim ve hasılatı hakkında tamamlayıcı araştırmalar. Journal of Faculty of Forestry, Istanbul University, Seri A, 17(1): 31-56 (In Turkish).

Fan Z, X Fan, MK Crosby, WK Moser, H He, MA Spetich, SR Shifley. 2012. Spatio-temporal trends of oak decline and mortality under periodic regional drought in the Ozark Highlands of Arkansas and Missouri. Forests 3(3): 614-631. DOI:10.3390/f3030614

Gaertig T, H Schack-Kirchner, EE Hildebrand, K Wilpert. 2002. The impact of soil aeration on oak decline in Southwestern Germany. Forest Ecology and Management 159: 15-25.

Haavik LJ, DW Stahle, FM Stephen. 2011. Temporal aspects of Quercus rubra decline and relationship to climate in the Ozark and Ouachita Mountains, Arkansas. Canadian Journal of Forest Research 41: 773-781.

Haavik LJ, SA Billings, JM Guldin, FM Stephen. 2015. Emergent insects, pathogens and drought shape changing patterns in oak decline in North America and Europe. Forest Ecology and Management 354: 190-205.

Kantarci MD. 2000. Toprak İlmi. ISBN 975-404-588-7. Istanbul, Turkey. 420 p. (In Turkish).

Kantarci MD, M Zengin, K Uluer. 2005. Trakya'da meşe ormanlarında meydana gelen kurumaların sebeplerinin 
belirlenmesi (Determination of the causes of oak forests' decline in Thrace). Ankara, Turkey. Turkish Ministry of Environment and Forest. 5 p. (In Turkish).

Kumbasli M, A Keten, V Beskardes, E Makineci, E Özdemir, E Yilmaz, H Zengin, O Sevgi, HC Yilmaz, S Caliskan. 2011. Hosts and distribution of yellow mistletoe (Loranthus europaeus Jacq. (Loranthaceae)) on Northern Strandjas Oak Forests-Turkey. Scientific Research and Essays 6(14): 2970-2975. DOI: 10.5897/SRE10.1178

Kuster TM, M Arend, P Bleuler, MS Günthardt-Goerg, R Schulin. 2013. Water regime and growth of young oak stands subjected to air-warming and drought on two different forest soils in a model ecosystem experiment. Plant Biology 15 (Suppl 1): 138-147. DOI:10.1111/j.1438-8677.2011.00552.x

Makineci E, E Yılmaz, E Özdemir, M Kumbaşlı, O Sevgi, A Keten, V Beşkardeş, H Zengin, H Yılmaz, S Çalışkan. 2011. Kuzey Trakya koruya tahvil meşe ekosistemlerinde sağlık durumu, biyokütle, karbon depolama ve faunistik özelliklerin belirlenmesi (Determination of health condition, biomass, carbon sequestration and faunistic characteristics on conversion of coppice oak ecosystems in Northern Thrace). Project Report, submitted to TUBITAK, project number: TOVAG 107O750. Ankara, Turkey. Scientific and Technological Research Council of Turkey. 260 p. (In Turkish).

Makineci E, E Ozdemir, S Caliskan, E Yilmaz, M Kumbasli, A Keten, V Beskardes, H Zengin, H Yilmaz. 2015. Ecosystem carbon pools of coppice-originated oak forests at different development stages. European Journal of Forest Research 134(2): 319-333. DOI 10.1007/s10342-014-0854-y

Millar CI, NL Stephenson. 2015. Temperate forest health in an era of emerging megadisturbance. Science 349: 823-826. DOI: $10.1126 /$ science.aaa9933

Nakajima H, M Ishida. 2014. Decline of Quercus crispula in abandoned coppice forests caused by secondary succession and Japanese oak wilt disease: Stand dynamics over twenty years. Forest Ecology and Management 334: 18-27.

Rampelberg S, B VanDerA, J Deckers. 1997. Soil morphology and soil water regime of loess soils under oak in the Meerdaal forest Belgium. Agricultural and Forest Meteorology 84: 51-59.

Sallé A, LM Nageleisen, F Lieutier. 2014. Bark and wood boring insects involved in oak declines in Europe: Current knowledge and future prospects in a context of climate change. Forest Ecology and Management 328: 79-93.

Shiffley SR, Z Fan, JM Kabrick, RG Jensen. 2006. Oak mortality risk factors and mortality estimation. Forest Ecology and Management 229: 16-26.

Sonesson K. 1999. Oak decline in Southern Sweden. Scandinavian Journal of Forest Research 14(4): 368-375.

Thomas FM, R Blank, G Hartmann. 2002. Abiotic and biotic factors and their interactions as causes of oak decline in Central Europe. Forest Pathology 32:277-307.

Tulik M, S Bijak. 2016. Are climatic factors responsible for the process of oak decline in Poland? Dendrochronologia 38: $18-25$.

UNECE (United Nations Economic Commission for Europe, $\mathrm{CH})$. 2004. Manual on methodologies and criteria for harmonized sampling, assessments, monitoring and analysis of effects of air pollution on forests. Geneva, Switzerland. Programme Co-ordinating Center, UNECE. 